\title{
Interactions of Biophysical and Socioeconomic Factors and Outputs in Mixed Crop-Livestock Smallholder Farming Systems in Africa South of the Sahara
}

\author{
Washington Muzari \\ Senior Lecturer, Department of Agricultural Engineering, Chinhoyi University of Technology, P. Bag 7724, Chinhoyi, Zimbabwe
}

\begin{abstract}
African mixed farming is a system in which various components (cropping, tillage, soil fertility, milk and meat production) are owned and managed as a single unit. Mixed crop-livestock farming systems constitute the backbone of much smallholder agriculture in the tropics, particularly in sub-Saharan Africa. Livestock provide many different products and services to people, such as food, income, manure, draft power, a store of wealth, and socio-cultural values. Mixed crop-livestock systems are characterized by a strong complementarity in resource use, with outputs from one component being supplied to other components. However, some trade-offs between farm components are also evident. Organic resources play a dominant role in smallholders' production and livelihood objectives. The organic resources are used for soil fertility management, animal feed, fuel, and fibre. Crop-livestock interactions and integration are influenced by a variety of socio-economic factors including climate, soils, population density, labour availability, land availability, market access, government policy, structural adjustment programmes, and trypanosomiasis threat. The increased variety of outputs produced in mixed smallholder crop-livestock systems reduces marketing risks associated with unexpected declines in the price of any one product. The application of remedial interventions in resource management is becoming a necessity for intensifying croplivestock systems where population density is on the rise, the farm size is declining, and competition for land, water, and other biophysical and socioeconomic resources among various sectors is increasing. Given the growing resource scarcity and the rising demand for agricultural products, appropriate resource allocation is needed to satisfy this demand and also safeguard environmental services of ecosystems at the same time. Sustaining and safeguarding environmental services in sub-Saharan Africa cannot be realized without controlling the expansion of grazing land and cropland into natural ecosystems, and limiting and reversing rangeland degradation. Diversification and intensification of smallholder agriculture appear the most effective pathways for achieving these outcomes. Participatory research approaches involving appropriate scientific disciplines, policy makers and farmers are needed for developing ecologically sound, economically viable and socially acceptable technologies that improve nutrient cycling and enhance agricultural productivity. Property rights have a profound effect on resource management. Thus secure rights to land, whether under communal or private regimes, are required for long-term resource management. Economic incentives (e.g. subsidies) and policies that encourage well-functioning input and output markets can have a strong impact on the choices that farmers make between alternative crop, livestock and nutrient management strategies.
\end{abstract}

Keywords: interactions, biophysical, socioeconomic, crop, livestock, smallholder

\section{Introduction}

Achieving sustainable increases in agricultural production in sub-Saharan Africa is both a regional and worldwide concern. High human and animal population densities in some areas have surpassed land carrying capacities, causing environmental degradation and undermining long-term stability of agricultural production systems. In attempts to meet the increasing food demands of larger populations, farmers are cultivating more land permanently; grazing lands have diminished; and many traditional farming practices that formerly allowed land to rejuvenate are disappearing (Powell et al., 1993). An efficient cycling of nutrients among crops, animals and soil is crucial to the sustained productivity of low-input mixed farming systems in sub-Saharan Africa. Access to agricultural inputs such as fertilizer and improved seeds is limited. Nutrient balances, or the difference between nutrient inputs and harvests, are negative for many production systems (Powell et al., 1993). Livestock, and particularly ruminants, have crucial roles to play in mixed crop-livestock farming systems. They provide draft power for land preparation, weeding and and transport (Descheemaeker et al., 2009; Wolmer, 1997; World Bank, 2006; Thornton, 2010). Farmers who adopt animal traction (draft power) can expand the area under crops by $25 \%$ or more (McIntire et al., 1992). However, draft power or animal traction requires high initial capital investment and is most common in African farming systems where high valueadded crops are grown.

African mixed farming is a system in which various components (cropping, tillage, soil fertility, milk and meat production) are owned and managed as a single unit (Wolmer,1992). Intensive mixed farming is seen as the most efficient and sustainable means of increasing food production (Winrock International, 1992). Mixed croplivestock farming systems constitute the backbone of much smallholder agriculture in the tropics, particularly in subSaharan Africa (Thornton \& Herrero, 2001). Smallholder production in mixed systems supports the livelihoods of almost two-thirds of the global population, the bulk of them in sub-Saharan Africa and South Asia (Herrero et al., 2010). There is little doubt that in the sub-region, increasing integration of crops and livestock is going to occur over at least the next 30 years. Globally, the next 20 years will see a massive increase in the demand for food of animal origin, with virtually all the increased demand coming from developing countries (Delgado et al., 1999). Mixed crop- 


\section{International Journal of Science and Research (IJSR) \\ ISSN (Online): 2319-7064 \\ Index Copernicus Value (2013): 6.14 | Impact Factor (2014): 5.611}

livestock systems provide over $50 \%$ of the world's meat and over $90 \%$ of its milk and are the most common form of livestock production in developing countries. In addition, mixed systems include some $70 \%$ of the poor livestock keepers (Thornton \& Herrero, 2001). Livestock numbers and composition affect the demand for feed hence crop residue management and utilization practices (Valbuena et al., nd).

\section{Livestock Product and Service Utilization}

Livestock provide many different products and services to people (ILRI, 2002; Peden et al., 2007). They have multiple roles in human society (Thornton, 2010) thus making an important contribution to rural livelihoods, with particular economic and social importance for the majority of poor smallholders in sub-Saharan Africa (Misturelli and Heffernan, 2001; Thornton et al., 2002). Cattle, sheep and goats contribute directly to household food needs and income and the gross domestic product. They also provide manure that sustains crop yields (Powell et al., 1993). Diversification into livestock production provides animal manure which is a source of organic fertilizer for crop enterprises or feed for fish enterprises. In addition, diversification into livestock production buffers food supply, reducing the climatic and price risks of crop production (World Bank, 2006).

Livestock manure can be used to maintain soil fertility, and can also be used for fuel or nutrient cycling between and within farms, which enables the sustainable functioning of mixed farming systems among smallholders (Thornton, 2010). Harvesting animal food products offer opportunities for increased income generation (Thornton \& Herrero, 2001). Animals also assume various socio-cultural roles and are a means to store wealth (ILRI, 2002). Livestock also serve as financial instruments by providing households with an alternative for storing savings or accumulated capital, and they can be sold and transformed into cash as needed (Thornton, 2010). For some poorer households, livestock can provide a means of income diversification to help deal with times of stress.

Livestock production is thus an important factor for smallholders to move out of poverty (Kristjanson et al., 2007; Burke et al., 2007). Livestock's contribution to livelihoods, particularly those of the poor in developing countries, is well recognized (Thornton, 2010). Livestock generate income by providing both food and non-food products that the household can sell in formal or informal markets. Non-food products such as wool, hides and skins are important sources of income in some regions.

Livestock also contribute substantially and directly to human health (Thornton, 2010). The consumption of animal products can alleviate nutritional deficiency, which is still widespread in much of Africa south of the Sahara, and secure a better child physical and mental development (Delgado, 2003; Speedy, 2003). For poor and undernourished people, particularly children, the addition of modest amounts of livestock products to their diets can have substantial benefits for physical and mental health (Neumann et al., 2003).
If animal breeds are managed well, pastures and rangelands also provide ecosystem services in terms of maintaining soil and water resources. In addition to their food security, human health, economic and environmental roles, livestock have important social and cultural roles (Thornton, 2010). In many parts of Africa south of the Sahara, social relationships are particularly defined in relation to livestock, and the size of the household's livestock holding may confer considerable social importance on it. The sharing of livestock with others is often a means to create or strengthen social relationships, through their use as dowry or bride price, as allocations to other family members, and as loans (Kitalyi et al., 2005). Social status in livestock-based communities is often associated with leadership and access to (and authority over) natural, physical and financial resources.

\section{Crop and livestock interactions}

The case for integrating animal and crop systems is based on the premise that by-products from the two systems are used on the same farm (Wolmer, 1997). Draft power, use of roughages and low quality feeds, closed nutrient cycling through the soil, plants and the animals' manure, and improved soil fertility contribute to overall higher outputs per animal (in livestock enterprises) and per hectare (in crop enterprises) (Mohammed Saleem, 1997). Some of the key aspects of crop-livestock integration, and their trade-offs, include manure, crop residues, other fodder sources, and animal traction. The complementarity between crops and livestock, such as the use of crop residues for animal feed, and animals for animal traction and manure for crop production, make mixed farming attractive to smallholder producers (Powell et al., 1993).

In smallholder farming systems that combine crop production and livestock husbandry (mixed systems), crop residues are usually an essential source of feed for livestock production, restricting their ability for mulching in crop production (Valbuena et al., nd). Crop residues are used for a variety of purposes, one of which is as livestock feed; the straw of cereals and grain legumes provides valuable livestock feed after harvest (Wolmer, 1997). Integrated crop and livestock production can enhance environmental sustainability by feeding crop residues to animals, thus improving nutrient cycling (World Bank, 2006). In integrated or mixed crop-livestock systems, cattle derive up to $45 \%$ of their total annual feed intake from crop residues, and up to $80 \%$ during critical periods (Sandford, 1988). Crop residues can be grazed in situ or gathered for stall feeding. Additionally in these systems, crop residues fulfill other functions such as providing fuel and additional income through sale.

Considerable debate prevails regarding the best use of crop residues. Some people argue that cereal stovers are best used by applying them to the bare soils of semi-arid sub-Saharan Africa to avoid severe erosion (Powell et al., 1993). However, the current strategy of farmers is to feed cereal stovers to animals and apply livestock manure to the soil. Berazneva et al. (2014) suggest that farmers behave in this way because of the long time-lag in realizing the agronomic benefits of leaving crop residues in their fields, as opposed 


\section{International Journal of Science and Research (IJSR) \\ ISSN (Online): 2319-7064 \\ Index Copernicus Value (2013): 6.14 | Impact Factor (2014): 5.611}

to the more immediate results obtained when they feed crop residues to their livestock. Nevertheless, the competition between livestock and soils for cereal stovers and other crop residues needs to be assessed in terms of the long-term trade-offs in plant, animal and soil productivity.

Crop residues have multiple competing applications. The removal of crop residues for use as feed for domestic animals and the use of residues for fuel are the driving forces responsible for depletion of the soil organic pool in the tropics and subtropics, leading to soil degradation, a decline in soil structure, severe erosion, emission of greenhouse gases, and water pollution (Lal, 2006). These soil degrading processes decrease agronomic productivity, reduce crop response to chemical fertilizer and other inputs, and require additional labour for ploughing (Berazneva, 2014).

The timing of operations like tilling and weeding has a clear effect on crop performance, yields, and crop water productivity. If tillage is delayed due to lack of draft animals, the ideal planting period might be missed so that the crop cannot respond to rainfall at the start of the rainy season and good crop development is compromised (Rockstrom and Baron, 2007). This link between animal and crop productivity is an important feature of mixed croplivestock systems.

In mixed crop-livestock systems and especially with resource-poor farmers, crop residues are a major source of fodder for ruminants (Devendra and Thomas, 2002). In these systems, dual purpose crops or food-feed crops are very common as the grain can be used for human consumption and the residues for livestock feed (Lenne et al., 2003).

Fertilizing, either by inorganic fertilizers or animal manure, improves soil fertility, with manure having the additional advantage of improving soil physical properties (Bationo et al., 2004). Manure application is usually a vital feature of complementarity between the crop and livestock components of mixed systems. However, this feedback loop can get lost when farmers are forced to fall back on dried dung for fuel in case of firewood scarcity.

Increasing the linkages between crop and livestock is an effective means by which plant nutrients can be rapidly cycled within and between farms. On the other hand, the factors driving intensification of smallholder mixed agriculture often lead to the expansion of cropped areas and more intensive cropping practices at the expense of grazing land (Thornton \& Herrero, 2001). In the face of declining grazing land, the potential of arable land to provide fodder for livestock must be enhanced, if the important role of livestock within the farm system for household welfare is to be maintained or developed.

The integration between crops and animals not only enhances agricultural production, but also improves household food intake and income, and provides a buffer against climate risks (Thornton, 2010). The integration of crop and livestock production offers possibilities for risk spreading (Ellis, 2000), which makes these systems especially adapted to semi-arid conditions. Mixed crop- livestock systems are characterized by a strong complementarity in resource use, with outputs from one component being supplied to other components (Devendra \& Thomas, 2002; Patharathy et al., 2005).

In sub-Saharan Africa, feeding grain to livestock is a common practice, but only $14 \%$ of the grains produced are fed to livestock (Speedy, 2003), of which much is fed to poultry, especially if it does not meet the standards for human consumption. Smallholders prefer to grow dual purpose crops that meet both the human needs for food (e.g. grains) and animal fodder (e.g. crop residues) (Lenne et al.,2003).

The primary causes for low livestock productivity in subSaharan Africa are the low quality and quantity of feed (Lenne et al., 2003; Benin et al., 2006; World Bank, 2007), the predominance of indigenous, low-yielding breeds, inadequate water resources for drinking purposes, the incidence of diseases, and high rates of livestock mortality (Nefassa \& Jabbar, 2008).

By making use of fodder trees within agro-forestry systems, different benefits can be obtained simultaneously. Besides providing biomass for fodder, appropriate multipurpose trees stabilize the land, decrease erosion, improve soil structure and fertility, and increase ecosystem stability (Roothaert and Franzel, 2001; Mekoya et al., 2008). Agroforestry systems, like alley cropping with fodder trees (Young, 1989; Sanchez, 1995), produce high quality fodder, while reducing losses in runoff (through improved soil cover and soil physical properties) and deep percolation (as the deep roots of the perennial vegetation pump up water). Besides that, intercropping and agroforestry are known to create a favourable microclimate and thereby reduce vapour pressure deficit at plant level, so that transpiration efficiency is increased (Rockstrom and Barron, 2007).

\section{Organic Resources, Crop and Livestock Interactions}

Organic resources play a dominant role in smallholders' production and livelihood objectives. The organic resources are used for animal feed, fuel, and fibre. They are also fundamental to maintaining soil fertility in tropical soils, depletion of which is considered to be one of the major biophysical causes of low per capita food production in subSaharan Africa (Berazneva et al., 2014). The allocation of maize residues to soil fertility management among smallholder farmers in sub-Saharan Africa is traded against the competing uses such as household energy and livestock feed. Applications of organic resources for soil fertility management are often not adopted due to labour or land constraints (Place et al., 2003).

Despite low energy content and their bulkiness, residues constitute an important source of energy in rural Africa south of the Sahara. Crop residues are stall-fed to domestic animals, or left in the fields for stubble-grazing. Residues are also used as sources of fibre, building materials, or burnt to become pest control additives and preservatives, among other uses. 


\section{International Journal of Science and Research (IJSR) \\ ISSN (Online): 2319-7064}

Index Copernicus Value (2013): 6.14 | Impact Factor (2014): 5.611

Increasing the soil carbon pool through recommended practices such as mulching, retention of crop residues, and use of manures and biosolids, has the potential to sequester carbon, reverse soil degradation processes, improve soil quality and increase food production, as well as a strong impact on offsetting fossil fuel emissions (Lal, 2006). Crop residues constitute a critical portion of the available organic resources for many smallholders. Crop residues are generally defined as all inedible (to humans) phytomass of agricultural production, such as cereal or legume straws, leaves, stalks, and tops of vegetables, sugar, oil and tuber crops, and the litter and prunings of nut and fruit trees (Berazneva et al., 2014). Returning these crop residues to the soil is essential for multiple reasons. These include the recycling of plant nutrients, namely macronutrients such as nitrogen, phosphorus and potassium, and micronutrients; sequestering soil carbon, improving soil physical, mechanical and hydrological properties, erosion control, and sustaining agronomic productivity of soils by decreasing losses and increasing use efficiency of other inputs (Lal, 2009).

The existing literature also confirms the existence of important trade-offs among different uses of crop residues. Production and utilization patterns of crop residues vary according to agricultural season, farm size, land use practices, soil fertility, household size and socioeconomic characteristics, and prevailing cultural practices. For example, Forres-Rojas et al. (2011) demonstrate that higher productivity of maize crops on more fertile soils or on farms more recently from forest, leads to higher productivity (per hectare) of maize residues. Crowley and Carter (2000) found that wealthy smallholders in Kenya use inorganic fertilizers, practice fallowing on a portion of their farm or incorporate maize stover for soil management to achieve higher crop yields, while poorer households obtain higher yields from using maize residues as fuel or livestock feed. This is in contrast to the findings of Rusinamhodzi et al. (2015) who concluded from a study of smallholder crop utilization that wealthier smallholder farmers in Zimbabwe benefit more by feeding crop residues to livestock, while poorer farmers are better off applying crop residues to increase crop yields. It is also often thought that crop residues are substitutes for fuelwood in consumption. The empirical evidence as to whether fuelwood and dung, or fuelwood and crop residues, are substitutes, however is mixed. (Amacher et al., 1993; Mekonnen \& Kohlin, 2008; Cooke et al., 2008).

When it comes to the estimation of the value of organic resources in sub-Saharan Africa and other parts of the developing world, the existing literature uses either a production or a substitution approach. The production approach estimates the value of crop residues by calculating changes in overall farm profits or physical changes in production by including a biomass production input (e.g. Lopez, 1997; Goldstein and Uldry, 2008; Klemick, 2011). Two recent studies (Teklewood, 2012; Magnan et al., 2012) model a system of allocation equations for farmyard manure to examine the role of returns to manure as energy and farming inputs in smallholder agriculture. Magnan et al. (2012) analyze the value of cereal stubble in a mixed croplivestock farming system in Morocco, and use the price of a market input (purchased feed) to derive the shadow price of cereal stubble. The substitution approach is more robust than the production approach because of the reliable estimates of quantities of both inputs and outputs.

There are several key interactions between the various crop and livestock components of the mixed farming system. The interactions between organic resources and livestock revolve mostly around the supply of nutrients and energy in feed, hence the need to use models capable of predicting animal performance from given plant characteristics. A substantial number of these models can be found in the literature and their use depends on research objectives, data availability and precision required (Illius and Allen, 1994; Herrero et al., 1998).

The nutritional inputs of livestock feed can be managed indirectly in a grazing or browsing situation, or directly, with feed offered to stall-fed livestock. In most grazing situations, animals have considerable freedom in choosing what to eat, although the manager can control length of access time. Stall-feeding is common in mixed farming systems because it allows farmers to exert more control over the valuable manure outputs of their animals. It also reduces the possibility of damage to crops that may be caused by free-ranging livestock (Thorne, 1998). In some systems, stall-fed livestock will be grazed as well, often at a particular time of the year when seasonal factors make this desirable (Thorne, 1998).

\section{Livestock and Land Interactions}

An obvious interaction between livestock and land is through the management of stocking rates, which plays a large part in defining the productivity of grazing systems (Humphreys, 1991). Modeling grazing systems has received substantial attention, and several examples of integrated models varying widely in degree and complexity can be found in the literature (e.g. Hanson et al., 1998; Blackburn and Kothmann, 1989; Thornley and Verberne, 1989).

The livestock-land interaction also includes the production of manure and compost, and the provision of draft animal power. Livestock play a key role in the cycling of nutrients to crops, wherever the two are associated (Powell et al., 1995). In general, draft animals are used as tools in the management of the soil through tillage operations, although their role in support of crop processing and marketing activities is important in some situations.

\section{Pasture and Livestock Interactions}

One explanation of the low quality and quantity of animal feeds in sub-Saharan Africa is that pastures are increasingly being relegated to marginal lands due to the expansion of cropland (Steinfeld et al., 2006). Some so-called pastures are abandoned croplands that no longer support cultivation because of totally degraded soils. However, low pasture productivity is not only related to its unfavourable conditions (including climate, topography and soils), but is also due to the fact that many pastures are common property (Costales et al., 2006). 


\section{International Journal of Science and Research (IJSR) \\ ISSN (Online): 2319-7064 \\ Index Copernicus Value (2013): 6.14 | Impact Factor (2014): 5.611}

\section{Water, Livestock and Crop Interactions}

Insufficient integration of water and livestock development in the past led to poverty aggravation, environmental degradation and missed opportunities for investment in both the livestock and water sub-sectors (Peden et al., 2006; 2007).

Access to water is probably the most important link between livestock, people and the environment, and a major influencing factor for the development of livestock production systems (Descheemaeker et al., 2009). The distribution of water and land resources dictates herd composition and livestock distribution, livelihood strategies of people and their coping mechanisms. For example in subSaharan Africa where water is in short supply, farmers have adapted to these changes through lifestyles such as transhumance or nomadism.

Livestock convert water and feed resources into high value goods and services. In crop-livestock farms, livestock-water relationships vary depending on the composition of animal herds, the production objectives of farmers, livestock and crop management practices, market links, and livestock health and productivity (Descheemaeker et al., 2009). For example, in areas of sub-Saharan Africa where draft power is an important animal output, farmers give priority to oxen for a high quantity and quality of feed. Hence, oxen are the major user of feed and water, but also exhibit invaluable outputs: farmers owning cattle can plough on time to capture early rainfall and plant early, which enables crops to escape droughts late in the season (Greyseels et al., 1986; Greyseels, 1988). On the other hand, in dairy systems in sub-Saharan Africa (e.g. Moll et al., 2007) lactating cows are the major consumers of feed and water, but in turn, they also generate the highest income among the herd.

Although water for livestock and servicing might be the most obvious user of water in livestock production systems, it constitutes only a minor part of total water consumption (Peden et al., 2007). Recent reports have indicated that the major water consumption in livestock systems is related to the transpiration of water for feed production, which is generally 50 to 100 times the amount of water for drinking (Singh et al., 2004; Peden et al., 2007). In cases where livestock are fed crop residues, and graze rangelands, which are unsuitable for crop production anyway, livestock make a very efficient use of available water (Peden et al., 2007).

Moreover, as goats and sheep have a more efficient water metabolism than large ruminants (Wilson, 1989), livestock systems dominated by small ruminants are found to be more water-efficient than those with large ruminants and equines. Animals derive their water from different sources (Sileshi et al., 2003; McGregor, 2004), such as water directly consumed by drinking and water consumption through feed intake. The amount of drinking water used varies from 20-50 litres per tropical livestock unit $(1 \mathrm{TLU}=250 \mathrm{kgs})$ per day and depends on the species, dry matter intake, composition of the feed, water content of the feed, liveweight of the animal, level of milk and meat production, physiological status of the animal, and the climate in which the animal is managed (King, 1983; Giger-Reverdin and Gihad, 1991).
Irrigation is an effective way to eliminate crop water stress and decrease yield losses during dry spells, thereby increasing crop production. Especially in drought-prone areas, supplemental irrigation (i.e. applying small amounts of irrigation water at critical times of the growing season), and deficit irrigation (i.e. applying less irrigation than is needed for maximal crop production) both aiming at optimal rather than maximal yields, are known to increase crop water productivity (Oweis and Hachum, 2006). In irrigation, nonproductive water losses can be reduced by improvements in irrigation water management, which includes among other things, minimizing conveyance and drainage losses through various techniques.

Water harvesting, defined as concentrating and diverting runoff from one area and storing it for subsequent beneficial use in another area (Oweis and Hachum, 2006), enhances the temporal distribution of water and leads to improvements in water productivity in mixed crop-livestock smallholder production systems. This stored water can be applied to crops or forages to bridge dry spells, or can be used for domestic purposes or animal drinking.

\section{Soil, Mulch, Manure, Crop, Feed and Livestock Interactions}

Most soils in sub-Saharan Africa are inherently infertile and require amendments in order to sustain crop yields. Inorganic fertilizers are costly and unavailable to most farmers. Since livestock are an integral component of many mixed farming systems, the manure they produce, when applied to the soil, constitutes a low cost nutrient source that sustains the yields of many cultivated areas (Powell et al., 1993). The potential fertilizer value of livestock manure is dependent on a number of critical factors such as the total nutrient content, which depends on fodder quality, manure storage practices and application strategies, and the mineralization rates of manure-bound nutrients into inorganic forms for plant uptake. Since nutrient mineralization and losses are highly influenced by manure handling, storage and land application techniques, improved animal manure and soil management practices that capture and recycle more nutrients could increase both crop and livestock productivity (Powell et al., 1993).

Manuring is viewed by many as the critical technological component driving agricultural intensification at its early stages (Turner, 1995). Animal manure makes nutrients more immediately accessible to crops than green manure or mulching, and allows the concentration of nutrients from more distant rangeland sources on farmers' fields. Manure from livestock may contribute as much as $35 \%$ of soil organic matter (Steinfield and de Haan, 1997).

In semi-arid environments, great seasonal and annual fluctuations in feed availability and quality affect the type and numbers of livestock that farmers keep, manure availability and quality, and the impact of manure on crop production (Powell et al., 1993). In addition, feed quality factors such as nitrogen, cell-wall contents, lignin and polyphenols influence the amount and forms of nutrient excretion by ruminants and their fate when applied to soils. High rates of manure application on sandy soils cause 


\section{International Journal of Science and Research (IJSR) \\ ISSN (Online): 2319-7064 \\ Index Copernicus Value (2013): 6.14 | Impact Factor (2014): 5.611}

leaching of organic carbon, nitrogen and phosphorus (Powell et al., 1993). Thus the application of small amounts of manure regularly would be more efficient than large doses applied at long intervals.

Poor soil fertility and low use of organic and inorganic fertilizers are the greatest constraints to agricultural productivity in the semi-arid tropics of sub-Saharan Africa. Long-term application of fertilizer alone can adversely affect soil base saturation and $\mathrm{pH}$ and create aluminium toxicity, leading to reductions in crop yields (Powell et al., 1993). These problems can be corrected through the efficient recycling of organic materials in combination with chemical fertilizers and by rotating nitrogen-fixing legumes with cereal crops. Information is needed for the predominant soils, climate and mixed systems of sub-Saharan Africa on the long-term feasibility and economic benefits of using crop residues and animal manures to build soil organic matter reserves. Information is also needed on the effect of the timing of organic matter application to soils and on mineralization and nutrient release.

Soil, with its physical, chemical and biological characteristics dictating productivity at the farm level, is one of the most important natural resources for feed production. Soil organic matter plays a key role in the maintenance of soil structure and, therefore, water holding capacity and infiltration. Mulching or leaving plant residues on the field after harvesting protects the soil against erosion while at the same time improving its physical and chemical properties through the increase in organic matter content (Vanlauwe et al., 2002). By covering the soil, mulches also minimize evaporative water losses.

Whereas mulching can improve water productivity through its impact on soil physical and chemical properties, it entails a reduced availability of crop residues for feed, which could lead to lower animal productivity. Especially in situations of feed scarcity, the decisions made by smallholder farmers on resource use will often prioritize animal survival above longer-term soil improvements (Descheemaeker et al., 2009). The need to cover their own food requirements and household expenses pushes smallholder farmers to favour practices with positive returns in the short term, such as the use of crop residues for feeding livestock, which may affect the sustainability of mixed crop-livestock systems in the long term (Valbuena et al., nd).

\section{Biophysical and Socioeconomic Drivers in Farmers' Decisions of Resource Use}

Crop-livestock interactions and integration are influenced by a variety of socio-economic factors including population density, labour availability, land availability, market proximity, government policy, structural adjustment programmes, and trypanosomiasis threat (Wolmer, 1997). Farmers' decisions on resource use in mixed crop-livestock farming systems are influenced by biophysical and socioeconomic drivers including climate, population dynamics, market access and other institutional mechanisms (Valbuena et al., nd). Similarities and differences in resource management are related to opportunities and constraints linked to specific biophysical and socioeconomic contexts or drivers.

Biophysical conditions influence the growing season, limiting cropping in drier areas with poorer soils. For example, increasing aridity and drought and population pressures are transforming the types and numbers of livestock kept by farmers in sub-Saharan Africa, which in turn affects the manure outputs and crop yields (Powell et al., 1993). Population characteristics exert pressure on resources and resource management differently. For example, areas of high population density reduce availability of grazing and farm size, thus exerting pressure on crop residues.

The biological processes that regulate nutrient flows in mixed farming systems are mediated mainly by socioeconomic factors (Powell et al., 1993). The way institutional arrangements mediate access to livestock, manure or fodder, cannot be disregarded. Institutions are broadly defined to include regularized practices or patterns of behaviour (Leach et al., 1997), such that the term encompasses arrangements like marriage, land tenure, markets, manure exchange contracts, labour and draft power sharing arrangements, and cultural prohibitions on certain types of work (Wolmer, 1997).

The manure supply is affected by factors such as herd size, grazing rights to communal rangeland and access to manure exchange contracts. Most aspects of intensified manure management depend on available labour to collect, process, transport and spread manure on cropland and cash to build corrals and to purchase animals and carts for transport. Viable returns to investment depend on market prices and adequate infrastructure to ensure delivery of inputs and marketing of farm produce (Powell et al., 1993).

Land tenure is a key institution in mediating access to grazing land, crop residues, and manure. Property rights in sub-Saharan Africa are related to ethnicity, length of settlement and production system. Tenure status of land also tends to affect farmers' decisions to adopt land improvements. Studies show, for example, that security of tenure is an important constraint on the adoption of fodder banks (Taylor-Powell and Ingawa, 1986) and alley farming (Jabbar, 1994).

Access to input/ output markets also affect the type of agricultural output and the level of demand for agricultural products. For example, ready access to milk markets in dairy producing areas changes the feeding requirements, which has implications for the demand for crop residues. Local and regional institutions also influence the ownership of farm resources or products like crop residues. Resource ownership may be based on the type or nature of the resource. For example in some areas, residues of teff and groundnuts are regarded as a private resource, while in other areas maize residues are seen as a group or open or communal grazing/ harvesting resource.

The degree of agricultural intensification has a strong influence on crop and livestock production, and the degree or level of interactions between inputs and outputs on smallholder mixed farms. In areas where irrigation and the 


\section{International Journal of Science and Research (IJSR) \\ ISSN (Online): 2319-7064 \\ Index Copernicus Value (2013): 6.14 | Impact Factor (2014): 5.611}

use of pesticides, herbicides and machinery are used, there is a higher degree of agricultural intensification and greater levels of crop production. In the case of maize, there is greater production of both grain (principally for human consumption) and biomass or crop residues (available for mulching, livestock feed, construction or fuel).

\section{Diversification and Intensification Smallholder Agriculture}

Future global food and fibre demand is expected to increase substantially as populations grow and average incomes rise. However the land and water resources that can be brought into production to satisfy this demand are limited in size and quality (World Bank, 2006). Agricultural systems must therefore intensify the use of land and water resources through more sustainable methods and through changing current production systems and diversifying into new and more productive enterprises.

Agricultural intensification is an increase in the productivity of existing land and water resources in the production of food and cash crops, livestock, forestry, and aquaculture. Generally associated with increased use of external inputs, intensification is now defined as the more efficient use of production inputs (World Bank, 2006). Increased productivity comes from the use of improved varieties of crops or trees, and breeds of livestock or fish, more efficient use of labour, and better farm management.

As human and animal population densities increase, more intensive methods of crop and animal management are adopted (Powell et al., 1993). Manure accumulated in corrals is spread on cropland and animal-powered transport is used for hauling feed to the homestead. Manure and other nutrient sources (leaf litter from savanna land and soils from termite mounds) are also transported to the croplands. Intensive dairying provides cash for the purchase of fertilizer which, when combined with manure, sustains high maize yields.

Mixed crop-livestock systems are widespread in semi-arid and sub-humid regions in the tropics (Steinfeld et al., 2006). With increasing population density and land scarcity, crop and livestock activities tend to integrate more intensively (McIntire et al., 1992; Jagtap and Amissah-Arthur; 1999; Thornton and Herrero, 2001; Parthasarathy et al., 2005). Important risks for smallholders to intensify livestock production exist in the form of natural resource degradation in general, and to water resource depletion and scarcity, in particular.

Diversification, which represents a change in the farm enterprise pattern to increase profitability or reduce risk, is one option for sustainable intensification (World Bank, 2006). Diversification at the smallholder farm level is the adoption of multiple production activities that are complementary in economical and/ or ecological dimensions. This complementarity contributes to the overall sustainability of the farming system. The diversification process generally involves introducing new activities into the farm enterprise, for example new crops, livestock, or processing methods, and reflects a reallocation of production resources and inputs as well as a change in the production methods and the outputs produced.

Farm-level diversification involving mixed production systems can exploit synergies and complementarities among different operations for more productive and more sustainable use of resources upon which farm systems depend (World Bank, 2006). Replacing monoculture systems with mixed systems can improve biodiversity and reduce production risks associated with droughts and pest infestations. The increased variety of outputs produced reduces marketing risks associated with unexpected declines in the price of any one product. Diversification may also allow labour and machinery requirements to be distributed more evenly throughout the year, seasonal cash flows to be better managed, the range of products to be broadened, and marketing risks to be reduced.

Diversification must be a market-oriented process, driven by consumer demand and initiated by private sector agents. However, public sector participation will remain critical in certain areas such as the regulatory and policy environment and the provision of pure or partial goods (e.g. infrastructure and research).

Integrated crop-livestock production is likely to become increasingly profitable given the large worldwide increase in demand for meat, milk and other products derived from animals. The suitability of many livestock enterprises to small-farm production holds considerable potential for poverty reduction (World Bank, 2006).

\section{The Livestock Revolution}

Population growth, urbanization, economic growth and flourishing markets all lead to the increasing demand for animal products (Delgado, 2003; Costales et al., 2006; Steinfeld et al., 2006). In addition, changing nutritional needs, driven by growing incomes and demographic transitions, result in an increase in the demand for animal products on a global scale (Speedy, 2003; Steinfeld et al., 2006). Over the past few decades, the demand for animal products has increased two or three times faster in developing countries than in developed countries (Delgado, 2003). However, in the rural areas of the poorer sub-Saharan African countries, population has increased faster than meat consumption, so that the per capita consumption of livestock products has declined.

The highest growth rates in consumption and production are achieved in poultry, pigs, eggs and milk production (Speedy, 2003). The livestock revolution (Delgado et al., 1999; Delgado, 2003) offers a chance for smallholders to benefit from the rapidly growing market and raise their incomes. Besides being an opportunity for poverty alleviation (World Bank, 2007), the livestock revolution can also lead to better nutrition and health, and to environmental preservation. Historical intensification and industrialization of the livestock sector in developed countries have led to very high levels of livestock productivity, which is in sharp contrast to the low livestock productivity in sub-Saharan Africa. 


\section{International Journal of Science and Research (IJSR) ISSN (Online): 2319-7064 \\ Index Copernicus Value (2013): 6.14 | Impact Factor (2014): 5.611}

\section{Conclusions and Recommendations}

Natural resources are already under huge pressure and solutions leading to an increase in crop and livestock productivity without using more water or causing further environmental degradation, are urgently required. The application of remedial interventions in resource management is becoming a necessity for intensifying croplivestock systems where population density is on the rise, the farm size is declining, and competition for land, water, and other biophysical and socioeconomic resources among various sectors is increasing.

Given the growing resource scarcity and the rising demand for agricultural products, appropriate resource allocation is needed to satisfy this demand and also safeguard environmental services of ecosystems at the same time. Sustaining and safeguarding environmental services in subSaharan Africa cannot be realized without controlling the expansion of grazing land and cropland into natural ecosystems, and limiting and reversing rangeland degradation. Diversification and intensification of smallholder agriculture appear the most effective pathways for achieving these outcomes.

The great demand on agriculture to produce more food and feed requires innovations that increase the efficiency of nutrient management. Given the current prohibitive costs of supplying external inputs such as fertilizers to crop and livestock producers, identifying the major points of nutrient loss and approaches for improving nutrient cycling are urgently needed.

The degree of crop-livestock integration in farming systems and pathways to intensification are diverse and depend on an array of biophysical and socioeconomic factors. These factors are mediated by the resources available and management practices of farmers. Appropriate technologies suited to the resources available to farmers continue to be needed as policies that provide incentives for more efficient resource use. Research and development efforts to improve food production need to recognize the diversity of mixed farming systems and the potential for improving crop and livestock production within each system. Participatory research approaches involving appropriate scientific disciplines, policy makers and farmers are needed for developing ecologically sound, economically viable and socially acceptable technologies that improve nutrient cycling and enhance agricultural productivity. Property rights have a profound effect on resource management. Thus secure rights to land, whether under communal or private regimes, are required for long-term resource management. Economic incentives (e.g. subsidies) and policies that encourage well-functioning input and output markets can have a strong impact on the choices that farmers make between alternative crop, livestock and nutrient management strategies.

\section{References}

[1] Amacher, G., Hyde, W. and Joshee, B. (1993). Joint production and consumption in traditional households:
Fuelwood and crop residues in two districts in Nepal. Journal of Development Studies 30: 206-225.

[2] Bationo, A., Nandwa, S.M., Kimethu, J.M., Kinyangi, J.M., Bado, B.V., Lompo, F., Kimani, S., Kihanda, F. and Koala, S. (2004). Sustainable intensification of crop-livestock systems through manure management in eastern and western Africa: Lessons learned and emerging research opportunities. In: Williams, T.O., Tarawali, S.A., Hiernaux, P. and Fernandez-Rivera, S. (Eds.) Sustainable crop-livestock production for improved livelihoods and natural resource management in West Africa. Proceedings of an international conference held at the International Institute of Tropical Agriculture (IITA), Ibadan, Nigeria, November 9-22, 2001. Nairobi, Kenya: International Livestock Research Institute (ILRI) and Wageingen, the Netherlands: Technical Centre for Agricultural and Rural Cooperation (CTA).

[3] Berazneva, J., Lee, D.R., Place, F., and Jakubson, G. (2014). Allocation and valuation of non-marketed crop residues in smallholder agriculture: the case of maize residues in western Kenya. New York, USA: Cornell University.

[4] Blackburn, H.D. and Kothmann, M.M. (1989). Forage dynamics model for use in range or pasture environments. Grass and Forage Science 44: 283-294.

[5] Cooke, P., Kohlin, G. and Hyde, W. (2008). Fuelwood, Forests and Community Management? Evidence from Household Studies. Environment and Development Economics 13: 103-135.

[6] Crowley, E. and Carter, S. (2000). Agrarian Change and the Changing Relationships Between Toil and Soil in Maragoli, Western Kenya (1900-1994). Human Ecology 28: 383-414.

[7] Delgado, C., Rosegrant, M., Steinfeld, H., Ehui, S. and Courbois, C. (1999). Livestock to 2020. The next food revolution. Food, Agriculture, and the Environment Discussion Paper 28. IFPRI/FAO/ILRI.

[8] Delgado, C.L. (2003). Rising consumption of meat and milk in developing countries has created a new food revolution. Journal of Nutrition 133: 3907S-3910S.

[9] Descheemaeker, K., Amede, T,. and Haileslassie, A. (2009). Livestock and Water Interactions in Mixed Crop-Livestock Farming Systems of Sub-Saharan Africa: Interventions for Improved Productivity. IWMI.

[10] Devendra, C. and Thomas, D. (2002). Crop-animal interactions in mixed farming systems in Asia. Agricultural Systems 71: 27-40.

[11] Ellis, F. (2000). The Determinants of Rural Livelihood Diversification in Developing Countries. Journal of Agricultural Economics 51: 289-302.

[12] Gigar-Reverdin, S. and Gihad, E.A. (1991). Water metabolism and intake in goats. In: Morand-Fehr, P. (Ed.). Goat nutrition. Wageingen, the Netherlands: Pudoc.

[13] Goldstein, M. and Uldry, C. (2008). The Profits of Power: Land Rights and Agricultural Investment in Ghana. Journal of Political Economy 116: 981-1022.

[14] Hanson, J.D., Skiles, J.W. and Parton, W.J. (1988). A multi-species model for rangeland plant communities. Ecological Modeling, 44: 89-123. 


\section{International Journal of Science and Research (IJSR) ISSN (Online): 2319-7064 \\ Index Copernicus Value (2013): 6.14 | Impact Factor (2014): 5.611}

[15] Herrero, M., Dent, J.B. and Fawcett, R.H. (1998). The plant/ animal interface in models of grazing systems. Agricultural Systems Modeling and Simulation. Marcel Dekker Publishers, New York, USA, pp. 495542.

[16] Herrero, M., Thornton, P.K., Notenbaert, A.M., Wood, S., Msangi, S. and Freeman, H.A. (2010). Smart Investments in Sustainable Food Production: Revisiting Mixed Crop-Livestock Systems. Science 327 ((5967): 822-825.

[17] Humphreys, L.R. (1991). Tropical Pasture Utilization. Cambridge University Press, Cambridge, UK.

[18] Illius, A.W. and Allen, M.S. (1994). Assessing forage quality using integrated models of intake and digestion of ruminants. American Society of Agronomy, Madison, USA.

[19] ILRI (2002). Livestock - a pathway out of poverty: ILRI's strategy to 2010. International Livestock Research Institute, Nairobi, Kenya.

[20] Jabbar, M.A. (1994). 'ILCA/LTC research on property rights and alley farming in West Africa'. In Swallow, B.M. (Ed.) (1994). 'Evaluating the relationships between property rights, risk, technology and productivity in sub-Saharan Africa.' Socio- Economics and Policy Research Working Document, No. 18. Addis Ababa: International Livestock Centre for Africa.

[21] Jagtap, S. and Amissah-Arthur, A. (1999). Stratification and synthesis of crop-livestock production system using GIS. GeoJournal 47: 573-582.

[22] King, J. (1983). Livestock Water Needs in Pastoral Africa in Relation to Climate and Forage. ILCA Research Report 7. Addis Ababa, Ethiopia: International Livestock Centre for Africa.

[23] Kitalyi, A., Mtenga, L., Morton, J.U. McLeod, A., Thornton, P., Dorward, A. and Saadullah, M. (2005). Why keep livestock if you are poor. In Owen, E., Kitalyi, A. Jayasuriay, N. and Smith, T. (Eds.). Livestock and wealth creation: improving the husbandry of animals kept by resource-poor people in developing countries. Nottingham, UK: Nottingham University Press.

[24] Lal, R. (2006). Enhancing crop yields in the developing countries through restoration of the soil organic carbon pool in agricultural lands. Land Degradation and Development 17: 197-209.

[25] Lal, R. (2009). Soil quality impacts of residue removal for bioethanol production. Soil and Tillage Research 102: 233-241.

[26] Leach, M., Mearns, R. and Scoones, I. (1997). 'Environmental Entitlements: A Framework for Understanding the Institutional Dynamics of Environmental Change'. IDS Discussion Paper No. 359. Brighton: Institute of Development Studies.

[27] Lenne, J., Fernandez-Rivera, S. and Blummel, M. (2003). Approaches to improve the utilization of foodfeed crops - synthesis. Field Crops Research 84: 213222.

[28] Lopez, R. (1997). Environmental externalities in traditional agriculture and the impact of trade liberalization: the case of Ghana. Journal of Development Economics 53: 17-39.
[29] McGregor, B.A. (2004). Water quality and provision for goats. Report Phase 2. A report for the Rural Industries Research and Development Corporation. RIRDC publication no. 04/036, project no. DAV 202A.

[30] McIntire, J., Bourzat, D. and Pingali, P. (1992). Croplivestock interactions in Sub-Saharan Africa. Washington, DC: World Bank.

[31] Mekonnen, A. and kohlin, G. (2008). Biomass Fuel Consumption and Dung Use as Manure: Evidence from Rural Households in the Amhara Region of Ethiopia. EfD Discussion Paper No. 08-17. Washington, DC: Environment for Development Initiative and Resources for the Future.

[32] Mekoya, A., Oosting, S., Fernandez-Rivera, S. and van derZijpp, A.J. (2008). Multipurpose fodder trees in the Ethiopian highlands: Farmers' preference and relationship of indigenous knowledge of feed value with laboratory indicators. Agricultural Systems 96: 184-194.

[33] Misturelli, F., and Heffernan, C. (2001). Perceptions of poverty among poor livestock keepers in Kenya: A discourse analysis approach. Journal of International Development 13: 863-875.

[34] Mohammed Saleem, M.A. (1997). Comments made at the ILRI/FAO/IDRC/INFORUM E-Conference: 'Balancing Livestock, the Environment and Human Needs,' April 1997.

[35] Neumann, C.G. et al. (2003). Animal source foods improve dietary quality, micronutrient status, growth and cognitive function in Kenyan school children: background, study design and baseline findings. Journal of Nutrition, 133: 3941S - 3049S.

[36] Oweis, T. and Hachum, A. (2006). Water harvesting and supplemental irrigation for improved water productivity of dry farming systems in West Asia and North Africa. Agricultural Water Management 80: 5773.

[37] Parthasarathy Rao, P., Birthal, P.S. and Ndjeunga, J. (2005). Crop-livestock economies in the semi-arid tropics: Facts, trends and outlook. Patancheru, Andhra Pradesh, India: International Crops Research Institute for the Semi-Arid Tropics (ICRISAT).

[38] Peden D., Freeman, A., Astatke, A. and Notenbaert, A. (2006). Investment options for integrated waterlivestock-crop production in sub-Saharan Africa. Working Paper 1. Nairobi, Kenya: International Livestock Research Institute.

[39] Peden, D., Tadesse, G., and Mammo, M. (2002). Water and livestock in human development. In: Water for Food, Water for Life: a Comprehensive Assessment of Water Management in Agriculture. Pp.485-514. Sri Lanka: IWMI.

[40] Place, F., Barret, C.B., Freeman, H., Ramisch, J.J. and Vanlauwe, B. (2003). Prospects for integrated soil fertility management using organic and inorganic inputs: evidence from smallholder African agricultural systems. Food Policy 28: 365-378.

[41] Powell, J.M., Fernandez-Rivera, S. Williams, T.O. and Renard, C. (Eds.) (1995). Livestock and Sustainable Nutrient Cycling in Mixed Farming Systems of SubSaharan Africa. Proceedings of an International 


\section{International Journal of Science and Research (IJSR) ISSN (Online): 2319-7064}

Index Copernicus Value (2013): 6.14 | Impact Factor (2014): 5.611

Conference held in Addis Ababa, Ethiopia, 22-26 November 1993. ILCA.

[42] Powell, J.M., Fernandez-Rivera, S., Williams, T.O. and Renard, C. (1993). Livestock and Sustainable Nutrient Cycling in Mixed Farming Systems of subSaharan Africa. Volume 1: Conference Summary. Proceedings of an International Conference, International Livestock Centre for Africa (ILCA), Addis Ababa, Ethiopia, 22-26 November 1993.

[43] Rockstrom, J. and Barron, J. (2007). Water productivity in rainfed systems: Overview of challenges and analysis of opportunities in water scarcity prone savannahs. Irrigation Science 25: 299311.

[44] Roothaert, R. and Franzel, S. (2001). Farmers' preferences and use of local fodder trees and shrubs in Kenya. Agroforestry Systems 52: 239-252

[45] Rusinamhodzi, L., van Wijk, M.T. , Corbeels, M., Rufino, M.C. and Giller, K.E. (2015). Maize crop residue uses and trade-offs on smallholder croplivestock farms in Zimbabwe: Economic implications for intensification. Agriculture, Ecosystems and Environment 214 (2015): 31-45.

[46] Sanchez, P.A. (1995). Science in agroforestry. Agroforestry Systems 30: 5-55.

[47] Sandford, S. (1988). Integrated cropping-livestock systems for dryland farming in Africa. In Unger P.W., Jordon, W.R., Sneed, T.V. and Jensen R.W. (Eds.). Challenges in Dryland Agriculture: A Global Perspective. Proceedings of the International Conference on Dryland Farming, 15-19 August, 1988, Amarillo/Bushland, Texas.

[48] Scoones, I. and Toulmin, C. (1995). 'Socio-economic dimensions of nutrient cycling in agropastoral systems in dryland Africa. In Powell, J.M., Fernandez-Rivera, S., Williams, T.O. and Renard, C. (Eds.). Livestock and Sustainable Nutrient Cycling in Mixed Farming Systems of sub-Saharan Africa. Vol. 2: Technical Papers. Addis Ababa: International Livestock Centre for Africa.

[49] Sileshi, Z., Tegegne, A. and Tsadik, G. (2003). Improving water productivity of livestock: An opportunity for poverty reduction. In: McCornick, P.G., Kamara, A.B. and Tadesse, G. (Eds.) Integrated water and land management research and capacity building priorities for Ethiopia. Proceedings of a MoWR/EARO?IWMI/ILRI international workshop held at ILRI, Addis Ababa, Ethiopia, December 2-4, 2002. Colombo, Sri Lanka: International Water Management Institute (IWMI) and Nairobi, Kenya: International Livestock Research Institute (ILRI).

[50] Speedy, A.W. (2003). Global production and consumption of animal source foods. Journal of Nutrition 133: 4048S-4053S.

[51] Steinfeld, H., Gerber, P., Wassenaar, T., Castel, V., Rosales, M. and de Haan, C. (2006). Livestock's long shadow. Environmental issues and options. Rome, Italy: Food and Agriculture Organization of the United Nations.

[52] Steinfield, H. and de Haan, C. (1997). Livestock, Environment and Human Needs: Summary Results of a Multi-Donor Study. Washington, DC: The World Bank.
[53] Taylor-Powell, E. and Ingawa, S.A. (1986). 'Beneficiary reactions to fodder bank trials.' In von Kaufman, R., Chater, S. and R. Blench (Eds.) Livestock Systems Research in Nigeria's Subhumid Zone. Addis Ababa, Ethiopia, ILCA: 365-381

[54] Thorne, P.J. (1998). Crop-Livestock Interactions: A review of opportunities for developing integrated models (Consultant's Report, Systems Analysis and Impact Assessment Project). ILRI, Nairobi, Kenya.

[55] Thornley, J.H.M. and Verberne, E.L.J. (1989). A model of nitrogen flows in grassland. Plant, Cell and Environment 12: 863-886.

[56] Thornton, P., Kruska, R., Henninger, N., Kristjanson, P., Reid, R., Atieno, F., Odero, A. and Ndegwa, T. (2002). Mapping Poverty and Livestock in the Developing World. Nairobi, Kenya: International Livestock Research Institute.

[57] Thornton, P.K. (2010). Livestock production: recent trends, future prospects. Philosophical Transactions of the Royal Society B: Biological Sciences, 365 (1554): 2853-2867.

[58] Thornton, P.K. and Herrero, M. (2001). Integrated crop-livestock simulation models for scenario analysis and impact assessment. Agricultural Systems 70 (2001): $581-602$.

[59] Torres-Rojas, D. Lehman, J., Hobbs, P., Joseph, S. and Neufeldt, H. (2011). Biomass availability, energy consumption and biochar production in rural households of Western Kenya. Biomass and Bioenergy 35: 3537-3546.

[60] Turner, M.D. (1995). The Sustainability of Rangeland to Cropland Nutrient Transfer in Semi-Arid; Ecological and Social Dimensions Neglected in the Debate. In Powell, J.M., Fernandez-Rivera, S., Williams, T.O. and Renard, C. (Eds.). Livestock and Sustainable Nutrient Cycling in Mixed Farming Systems of sub-Saharan Africa. Vol. 2: Technical Papers. Addis Ababa: International Livestock Centre for Africa.

[61] Valbuena, D., Gerard, B. Duncan, Teufel, N., Homann, S. and Bhatia, M. (nd). Trade-offs of crop residue use in smallholder mixed farming systems in sub-Saharan Africa and South Asia. SLP/ ILRI/ICRISAT/CIMMYT.

[62] Vanlauwe, B., Diels, J., Sanginga, N. and Merckx, R. (eds.). Integrated plant nutrient management in SubSaharan Africa: From concept to practice. UK: CABI Publishing.

[63] Wilson, R.T. (1989). Ecophysiology of the Camelidae and Desert Ruminants. New York: Springer-Verlag.

[64] Winrock International (1992). Assessment of Animal Agriculture in Sub-Saharann Africa. Mirrilton: Winrock International.

[65] Wolmer, W. (1997). Crop-livestock integration: the dynamics of intensification in contrasting agroecological zones: A Review. IDS Working Paper 63. IDS, University of Sussex.

[66] World Bank (2006). Agriculture Investment Sourcebook, Module 4: Investments in Sustainable Agricultural Intensification. Washington, DC: World Bank. 


\section{International Journal of Science and Research (IJSR) \\ ISSN (Online): 2319-7064}

Index Copernicus Value (2013): 6.14 | Impact Factor (2014): 5.611

[67] World Bank (2007). World Development Report 2008. Agriculture for Development. Washington, D.C.: World Bank.

[68] Young, A. (1989). Agroforestry for soil conservation. Wallingford, UK: CAB International. 